\title{
Replication status of the fragile $X$ chromosome and its implications for reproductive performance in the Indian mole rat (Nesokia indica)
}

\author{
Rita Tewari and S. R. V. Rao \\ Cytogenetics Laboratory, Department of Zoology, University of Delhi, Delhi-110007, \\ India
}

\begin{abstract}
Summary. In all fertile females the fragile $X$ chromosome was almost always late replicating (inactive) in an average $82 \%$ of cells whereas in infertile females, it was early replicating (active) in about the same percentage of cells. These observations strongly suggest a correlation between the replication (activity) status of the fragile X chromosome and reproductive performance.
\end{abstract}

Keywords: fragile $\mathrm{X}$ chromosome; replication status; reproduction; Indian mole rat

\section{Introduction}

The Indian mole rat (Nesokia indica) is a fossorial rodent (adult weight approximately $250 \mathrm{~g}$ ) and has a diploid chromosome complement of 42 . The $\mathrm{X}$ chromosome which is metacentric (denoted as $\mathrm{X}^{\mathrm{m}}$ ) is the largest in the complement (composite type, $17 \cdot 34 \%$ of total chromosome length (TCL)) and has a euchromatic short arm and a heterochromatic long arm (10.9\% TCL). The totally heterochromatic $\mathrm{Y}$ chromosome, which is also metacentric $\left(\mathrm{Y}^{\mathrm{m}}\right)$, is the second largest in the complement (11.33\% TCL).

Mole rats of this species are characterized by an extensive polymorphism of the sex chromosomal heterochromatin. The four polymorphic X-chromosome types arise due to deletion of heterochromatin at four specific sites and are designated as $\mathrm{X}^{\mathrm{dl}} 1, \mathrm{X}^{\mathrm{dl}} 2, \mathrm{X}^{\mathrm{dl}} 3$ and $\mathrm{X}^{\mathrm{a}}$ (Rao et al., 1983; Thelma et al., 1988). These sites also correspond to 4 folate-sensitive fragile sites which have been termed fraXq1, fraXq2, fraXq3 and fraXc (Tewari et al., 1987). These sites have been observed in every female mole rat examined so far. In all fertile females with $\mathrm{X}^{\mathrm{m}} \mathrm{X}^{\mathrm{m}}$ constitution one or more fragile sites are expressed on only one of the two X chromosomes in about $30-40 \%$ of cells (heterozygous expression). However, in infertile females with a similar $\mathrm{X}^{\mathrm{m}} \mathrm{X}^{\mathrm{m}}$ constitution, these sites are not only expressed in a much higher frequency (around 70\%) but, in about $4-10 \%$ of cells, both of the $\mathrm{X}$ chromosomes express these sites (double heterozygous/homozygous expression). The single active $\mathrm{X}$ chromosome in fertile males $\left(\mathrm{X}^{\mathrm{m}} \mathrm{Y}^{\mathrm{m}}\right)$ never expresses fragile sites but in infertile males $4-13 \%$ of cells express these sites on the $X$ chromosome (hemizygous expression) (Tewari et al., 1987). These observations prompted study of whether there was a correlation between the replication status of the fragile $\mathrm{X}$ chromosome and reproductive performance.

\section{Materials and Methods}

Animals. The study used 14 female mole rats ( 10 from the wild and 4 laboratory bred) with either an entire composite type $\mathrm{X}$ chromosome $\left(\mathrm{X}^{\mathrm{m}}\right)$ or with polymorphic $\mathrm{X}$ chromosome types $\left(\mathrm{X}^{\mathrm{dl}} 1, \mathrm{X}^{\mathrm{dl}} 2\right)$. The females were $4-8$ months of age; 9 individuals were proved fertile while 5 were unable to reproduce even after prolonged periods of mating with fertile males (Thelma et al., 1988). 

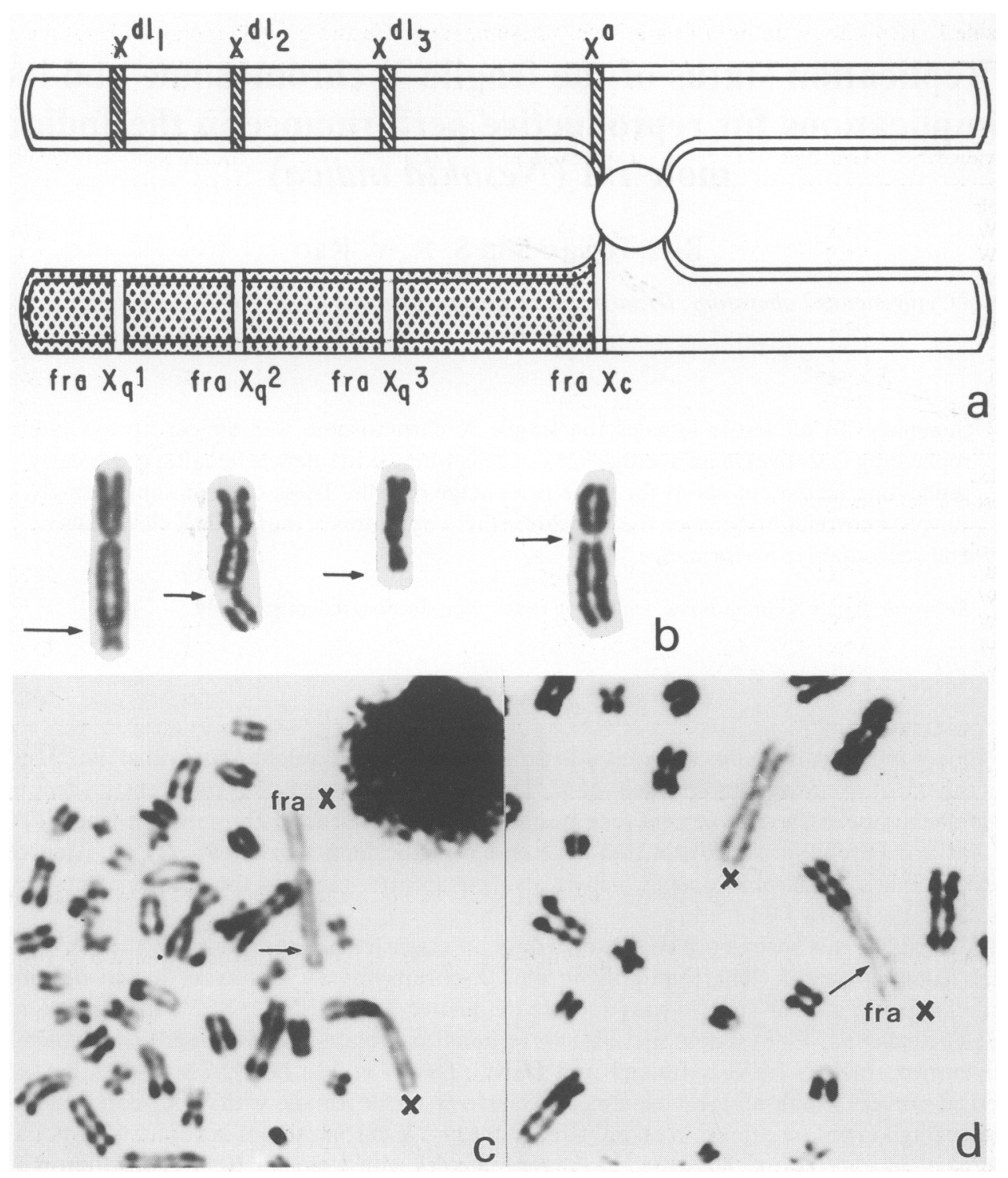

Fig. 1. Chromosomes of the Indian mole rat. (a) Diagrammatic representation of the composite $\mathrm{X}$-chromosome showing deletion sites on one chromatid and fragile sites on the other chromatid. The stipled portion represents constitutive heterochromatin. (b) Cut-outs of the X chromosome showing a fragile site $(\rightarrow)$ fraXql as a non-staining region, fraXq2 as a chromatid break, fraXq 3 as a chromosome deletion, and fraXc as a chromosome break near the centromere. (c) and (d) Partial metaphases from females (fertile and infertile respectively) showing a late replicating $\mathrm{X}$ chromosome with a fragile site $(\mathrm{fraXq} 1 \rightarrow$ ) $(\mathrm{c})$ and an early replicating $\mathrm{X}$ chromosome with a fragile site $($ fraXq2 $\rightarrow)(d)$.

Cultures. Heparinized blood withdrawn from the retino-orbital sinus of mole rats anaesthetized lightly with ether was cultured in folic acid-deficient McCoy's medium 5a (Centron Labs, Bombay, India) for detection of fragile sites. Simultaneously, control cultures were grown in RPMI medium for all the individuals. All cultures of $5 \mathrm{ml}$ each were supplemented with $10 \mu \mathrm{g}$ phytohaemagglutinin/ml (HA17, Wellcome Diagnostics, Dartford, UK) and $5 \%$ bovine calf serum. Cultures were incubated for $52 \mathrm{~h}$ at $37^{\circ} \mathrm{C}$. To identify the late replicating $\mathrm{X}$ chromosome by differential labelling, 5-bromo 2-deoxyuridine $(\mathrm{BrdU} ; 10 \mu \mathrm{g} / \mathrm{ml})$ was added $6.5 \mathrm{~h}$ before harvest. Colchicine $(0.03 \mu \mathrm{g} / \mathrm{ml})$ was 
Table 1. Replication status of fragile $X$ chromosomes in fertile and infertile Indian mole rat females

\begin{tabular}{|c|c|c|c|c|c|}
\hline \multirow[b]{2}{*}{ Individuals* } & \multirow[b]{2}{*}{ Genotype } & \multirow{2}{*}{$\begin{array}{l}\text { Total no. of } \\
\text { cells scored } \\
\text { (no. with fraX) }\end{array}$} & \multicolumn{2}{|c|}{ No. of cells with: } & \multirow[b]{2}{*}{$\mathrm{G}$ value $\dagger$} \\
\hline & & & $\begin{array}{l}\text { Late replicating } \\
\text { fragile } X\end{array}$ & $\begin{array}{l}\text { Early replicating } \\
\quad \text { fragile } X\end{array}$ & \\
\hline \multicolumn{6}{|l|}{ Fertile } \\
\hline $1 \mathrm{PW}$ & $X^{m} X^{m}$ & $95 \quad(39)$ & 31 & 5 & 20.89 \\
\hline $2 \mathrm{PW}$ & $\mathrm{X}^{\mathrm{m}} \mathrm{X}^{\mathrm{m}}$ & $75 \quad(20)$ & 7 & 1 & 5.05 \\
\hline $3 \mathrm{PW}$ & $\mathrm{X}^{\mathrm{m}} \mathrm{X}^{\mathrm{m}}$ & $95 \quad(29)$ & 14 & 1 & $13 \cdot 44$ \\
\hline $4 \mathrm{PW}$ & $X^{\mathbf{m}} \mathbf{X}^{\mathbf{m}}$ & 42 (13) & 8 & 4 & $1 \cdot 35$ \\
\hline $5 \mathrm{PW}$ & $\mathrm{X}^{\mathrm{m}} \mathbf{X}^{\mathrm{m}}$ & 77 (21) & 11 & 3 & $4 \cdot 85$ \\
\hline $6 \mathrm{Fl}$ & $X^{m} X^{m}$ & $91(46)$ & 14 & 5 & 4.43 \\
\hline $7 \mathrm{FI}$ & $\mathrm{X}^{\mathrm{m}} \mathbf{X}^{\mathrm{m}}$ & 141 (36) & 8 & 2 & 3.85 \\
\hline $8 \mathrm{~F} 2$ & $\mathrm{X}^{\mathrm{m}} \mathrm{X}^{\mathrm{m}}$ & $102(21)$ & 5 & 1 & $2 \cdot 91$ \\
\hline $9 \mathrm{~F} 2$ & $X^{m} X^{m}$ & 59 (14) & 6 & 1 & 3.96 \\
\hline \multicolumn{3}{|c|}{$\begin{array}{l}\text { Pooled } \\
\text { G-test of heterogeneity }\left(G_{H}\right)\end{array}$} & 104 & 23 & $\begin{array}{c}60 \cdot 73 \\
-4 \cdot 888 \ddagger\end{array}$ \\
\hline \multirow{6}{*}{$\begin{array}{l}\text { Infertile } \\
1 \text { PW } \\
2 \text { PW } \\
3 \text { PW } \\
4 \text { PW } \\
5 \text { PW }\end{array}$} & & & & & \\
\hline & $X^{m} X^{m}$ & $40 \quad(35) \S$ & 6 & 20 & $17 \cdot 22$ \\
\hline & $X^{m} X^{m}$ & $92(77) \S$ & 5 & 15 & $5 \cdot 23$ \\
\hline & $\mathrm{X}^{\mathrm{m}} \mathrm{X}^{\mathrm{m}}$ & $67(19) \S$ & 3 & 14 & $7 \cdot 22$ \\
\hline & $\mathrm{X}^{\mathrm{m}} \mathrm{X}^{\mathrm{dl}} 1 / \mathrm{X}^{\mathrm{m}} \mathrm{X}^{\mathrm{dl}} 2$ & $206(137) \S$ & 21 & 116 & $72 \cdot 54$ \\
\hline & $\begin{array}{l}X^{\mathrm{m}} \mathbf{X}^{\mathrm{d}} 1 / \mathbf{X}^{\mathrm{m}} \mathbf{X}^{\mathrm{dl}} 2 / \\
X^{\mathrm{dl}} 1 \mathbf{X}^{\mathrm{d} 1} 2\end{array}$ & $96(50) 8$ & 11 & 39 & 16.62 \\
\hline \multicolumn{3}{|c|}{$\begin{array}{l}\text { Pooled } \\
\text { G-test of heterogeneity }\left(G_{H}\right)\end{array}$} & 46 & 204 & $\begin{array}{l}118.83 \\
-2.213 \ddagger\end{array}$ \\
\hline
\end{tabular}

Comparable numbers of metaphases scored in control cultures showed no fragile sites.

*PW = parental generation, wild population; $\mathrm{F} 1=$ first generation; $F 2=$ second generation.

+ All values except $\ddagger$ are significant $(P<0.05)$.

$\$ 3-8 \%$ of these cells expressed fragile sites on both the $\mathrm{X}$ chromosomes (homozygous expression) in this category.

added $4 \mathrm{~h}$ before harvest. Chromosomes were prepared by a standard air-drying technique followed by fluorescence plus Giemsa staining (Perry \& Wolff, 1974).

\section{Results}

Fragile sites were not observed in any control cultures grown from the 14 individuals. However, in cultures grown in folate-deficient media fragile site(s) on the X chromosome(s) (fraXq1, fraXq2, fraXq3 and fraXc) were observed for all the animals. These sites were characterized by non-staining region(s), chromatid break(s) and/or chromosome break(s)/deletion(s) (Fig. 1b). Of the 4 sites the most frequently expressed were fraXq1 and fraXq2 which were evident as chromosome breaks or deletions. The resultant acentric fragments were, however, rarely observed in the metaphases scored. Apparently, they are either eliminated from the cells or form micronuclei (unpublished). The triradials characteristic of the fragile sites in man were not seen in mole rats.

Since all 4 fragile sites observed were only due to folate deficiency, all cells expressing one or more of these sites on any one of their two $\mathrm{X}$ chromosomes were considered for the analysis of fragile $\mathrm{X}$ chromosome. Of these only those in which the short arm of the two X chromosomes were differentially labelled with BrdU were included for the evaluation of early and late replicating fragile X chromosomes. Analyses of the replication status (early/late) of the fragile X chromosome revealed that, in a majority of the cells of fertile females, the fragile $X$ chromosome was late replicating (Fig. 1c) whereas in infertile females it was early replicating (Fig. 1d; Table 1). A Gtest of significance (Sokal \& Rohlf, 1969) for each of these categories substantiated the non- 
random expression. The pooled G-test of heterogeneity within each category was not significant (Table 1).

\section{Discussion}

A non-random association between the functional status of the fragile $\mathrm{X}$ chromosome and fertility status of the individual is apparent from this study. It is well known that in somatic cells of all mammalian females one of the two $\mathrm{X}$ chromosomes is inactivated and therefore only one $\mathrm{X}$ chromosome remains functional. When expressed on the inactive $\mathrm{X}$ chromosome, fragile sites seem to be inconsequential, as shown by females with proven fertility. However, when fragility is expressed on the active $\mathrm{X}$ chromosome in a female it seems to be invariably coupled with reproductive inability. This probably suggests that some sequences located at these specific sites (corresponding to fragile sites) on the $\mathrm{X}$ chromosome influence the orchestrated events ultimately resulting in reproductive ability. We suggested that, when these specific sequences on the active $X$ chromosome become non-functional due to one or more new mutations, these sequences express fragility (like the inactive $\mathrm{X}$ chromosome sequences in fertile category but at a comparatively higher degree) and such females become infertile.

Such an association of these specific sequences with reproductive (in) ability derives additional support from the observation that the fragile sites on the single active $\mathrm{X}$ chromosome in males $\left(\mathrm{X}^{\mathrm{m}} \mathrm{Y}^{\mathrm{m}}\right)$ are found only in the infertile individuals but not in the fertile males (Tewari et al., 1987). In addition, males with deleted $X$ chromosome heterochromatin $\left(X^{\mathrm{dl}} 2 Y^{\mathrm{m}} ; X^{\mathrm{m}} Y^{\mathrm{m}} / X^{\mathrm{dl}} 3 \mathrm{Y}^{\mathrm{m}} / \mathrm{X}^{\mathrm{a}} Y^{\mathrm{m}}\right.$, mosaic constitution of animal caught from wild), in which there has been a loss of such specific sequences, are also sterile and show both meiotic and structural abnormalities (Juyal et al., 1989). Structural anomalies in the gonads and infertility have also been reported for men with fragile $\mathrm{X}$ chromosome (Johannisson et al., 1987).

Therefore, considering that some human carrier females of the fragile $\mathrm{X}$ chromosome tend not to reproduce (Sherman et al., 1985), it may be of interest to assess the functional status of the fragile $\mathrm{X}$ chromosome in such cases.

We thank Dr B. K. Thelma and Dr R. C. Juyal for comments; and Professor F. Anders and Dr Klaus Lepper, University of Giessen, and Dr Heide Neitzel, Freie University, Berlin, West Germany, for the gift of phytohaemagglutinin (PHA HA17), Wellcome Diagnostics. R.T. is a recipient of Research Associateship from the C.S.I.R., New Delhi.

\section{References}

Johannisson, R., Rehder, H., Wendt, V. \& Schwinger, E. (1987) Spermatogenesis in two patients with the fragile $\mathrm{X}$ syndrome. I. Histology: light and electron microscopy. Hum. Genet. 76, 141-147.

Juyal, R.C., Thelma, B.K. \& Rao, S.R.V. (1989) Heterochromatin variation and spermatogenesis in Nesokia. Cytogenet. Cell Genet. 50, 206-210.

Perry, P. \& Wolf, S. (1974) New Giemsa method for differential staining of sister chromatids. Nature, Lond. 261, 156-158.

Rao, S.R.V., Vasantha, K., Thelma, B.K., Juyal, R.C. \& Jhanwar, S.C. (1983) Heterochromatin variation and sex chromosome polymorphism in Nesokia indica: a population study. Cytogenet. Cell Genet. 35, 233-237.

Sherman, S.L., Jacobs, P.A., Morton, N.E., FosterIskenius, V., Howard-Peebles, P.N., Nielson, K.B.,
Partington, M.W., Sutherland, G.R., Turner, G. \& Watson, M. (1985) Further segregation analysis of the fragile $\mathrm{X}$ syndrome with special reference to transmitting males. Hum. Genet. 69, 289-299.

Sokal, R.S. \& Rohlf, F.J. (1969) Biometry. W. H. Freeman \& Company, San Francisco.

Tewari, R., Juyal, R.C., Thelma, B.K., Das, B.C. \& Rao, S.R.V. (1987) Folate sensitive fragile sites on the Xchromosome heterochromatin of the Indian mole rat, Nesokia indica. Cytogenet. Cell Genet. 44, 11-17.

Thelma, B.K., Juyal, R.C., Tewari, R. \& Rao, S.R.V. (1988) Does heterochromatin variation potentiate speciation. A study in Nesokia. Cytogenet. Cell Genet. 47, 204-208. 